\title{
The Impact of the Euro on Information Systems
}

\author{
Daniel E. O'Leary \\ University of Southern California
}

\begin{abstract}
The European Economic Union (EEU) adopted a single currency, the "euro" on January 1, 1999. Such a development has far-reaching implications for development of information systems, the engines that will have to run and control the new monetary order. For example, euro-compliant systems will need to accommodate: (1) six decimal places, a major change for those companies in countries that did not require decimal places (e.g., Belgium and Italy), or even those that require only two, (2) "triangulation" between currencies rather than classic inversion, (3) multiple currencies for each transaction, and (4) differences between invoice amounts and amounts actually paid, since there can be rounding differences on conversions with triangulation. These changes are just the surface requirements for the euro currency change. Because the euro problem is very new, few companies have begun, let alone completed making, their euro systems changes. As a result, limited research is available regarding the euro. The purpose of this article is to help fill this void by examining the principal issues of the euro's impact on information systems and to identify research opportunities related to the euro problem.
\end{abstract}

Key Words: Euro, EMU, Y2K, Accounting information systems.

\section{INTRODUCTION}

Under the Treaty of Maastricht, the third stage of European economic and monetary union began on January 1, 1999, as part of the European Economic Union (EEU) change to a single currency (the "euro"). At that time the Economic and Monetary Union (EMU) became a new monetary force with an economic size roughly comparable to the United States or Japan. Many researchers (e.g., Henning 1997) argue that this change will begin a new era in international monetary relations. As a result, it is probably not surprising that the euro will force a number of wide-ranging changes to be made to information systems and to the way that business is done with and in EMU countries.

Converting information systems to accommodate the new currency will be difficult, but critical to the EMU's economy. As noted by Charles Brewer, a former chairperson of the United Kingdom information technology, banking, finance and insurance group CSSA (Computer Software and Systems Association), (Software Echo 1997, 1), "It may be that IT is the one issue that could stop the European Monetary Union in its tracks." Further, as reported in the Public Accounting Report $(1997,1)$ "the most important and immediate impacts of the Euro are accounting and technology implications...."

The purpose of this article is to explore the impact of the euro on accounting information systems, and to examine the infrastructure needed to implement those systems. The remainder of this article proceeds as follows. Section II provides a brief background into the euro and the EMU. Section III investigates the impact of the euro on accounting information system applications and compares the euro problem to the Year 2000 problem. Section IV considers the more general impact of the euro on

I would like to acknowledge the comments of Uday Murthy, Casper Wiggins, and the anonymous outside reviewers on two earlier versions of this article. 
business decision-making issues. The extent of preparedness of firms for the euro, alternatives available to solve the euro problem and the importance and role of euro system audits are reviewed. Section V outlines some related research issues and summarizes some of the opportunities that the euro provides to accountants and consultants. Exhibit 1 provides a set of related URLs and educational resources for further reference.

\section{EXHIBIT 1}

\section{Selected Web Page References and Educational Resources}

\section{General EMU References}

European Monetary Institute, http://www.ecb.int/

Europa, http://europa.eu.int/

History of the European Economic Union, http://cec.caixacat.es/euro/int2eng.html

"EMU and Euro Jargon,” http://news.bbc.co.uk/hi/english/special_report/single_currency/newsid_66000/ 66823.stm

EMU Net, http://www.euro-emu.co.uk/

EMU Lexicon, http://www.westlb.com/euro/

\section{Euro and Information Systems}

"Preparing Financial Information Systems for the Euro," http://www.ispo.cec.be/y2keuro/src/wdiseuro.htm

"Accounting and the Euro," http://europa.eu.int

\section{Computer Companies}

IBM, http://www.europe.ibm.com/euro/eurocentre/index.html

Microsoft Accounting, http://www.microsoft.com/europe/industry/accounting/

\section{Consulting Firms}

Deloitte and Touche, http://www.deloitte.co.uk/sectors/financial/euro.html

KPMG's Survey of Europe's Preparedness for EMU, http://www.kpmg.co.uk/uk/services/manage/emu.html KPMG's "Overview of the Tax and Audit Implications of the Euro, Edition 3.1," http://www.kpmg.com/ library/98/august/Eurobk3-1.pdf (available only in Adobe Acrobat)

Price Waterhouse, http://www.pwcglobal.com/extweb/newcojou.nsf/ docidmanagement/1879CD1859090357852566320076B390?opendocument

\section{Selected Banks}

Bank of England, http://www.bankofengland.co.uk/euroiss7.htm

Bundesbank, http://www.bundesbank.de/en/presse/wwu/eurokommt.htm

\section{Chartered Accountants}

The Institute of Chartered Accountants, http://www.icaew.co.uk/menus/links/links.htm

\section{Computer Magazines}

Computer World, http://www.computerworld.com/home/features.nsf/all/981005eurolinks

\section{Educational Resources}

Beyond the many text resources to study the euro, there are a number of emerging alternative educational resources for the "innovative" educator.

Cap Gemini (http://euro.capgemini.com/) have developed "euroka!" a business simulation in which participants explore the costs and benefits of being in the EMU. Participants manage a company through the key stages of adoption to a single currency. 


\section{EXHIBIT 1 (Continued)}

"Captain Euro" is a comic strip where the hero defends Europe from evil and "upholds the values of the Union." (Frank 1998, 1). Captain Euro comic books provide an introduction to some euro issues. http://itmatters.bworldonline.com/host/host_122498.html, http://www.captaineuro.com

Daniel E. O'Leary's Home Page for Advanced Technologies in Information Systems (ATISP)

This set of URLs and an updated one will be kept at the author's site, http://www.usc.edu/schools/business/atisp/AIS/EMU-References.htm

\section{BACKGROUND}

The euro is the currency of the EMU, and all member countries of the European Union will be able to join the EMU. Currently, Austria, Belgium, Finland, France, Germany, Ireland, Italy, Luxembourg, the Netherlands, Portugal and Spain have committed to use the euro as their currency. At this time, Denmark, Greece, Sweden and the United Kingdom are EEU members that have not committed to using the euro.

On January 1, 1999 the euro became a currency in its own right. At that time, conversion rates were fixed and the European Central Bank began conducting a single monetary and exchange rate policy in euros. On January 1, 1999, the actual value of the euro was set as summarized in Table 1. At that time interbank, monetary, capital and exchange markets began using euros. On January 1, 2002 euro notes and coins will be introduced for individual use. Local currencies will be withdrawn over the following six months and only the euro will be used after that.

As part of the implementation, the European Monetary Institute is replaced by a European Central Bank. The European Central Bank will oversee and control a European-based monetary policy and set a common interest rate.

\section{Conversion of Currencies to the Euro}

Most currency conversion systems use a straightforward multiplication and its inverse to generate a conversion from one currency to another and back. As would be expected, the choice of exchange rate and the number of significant digits used in the conversion can have an impact on the value and consistency of currency translation.

In order to illustrate inversion and other concepts that are part of the euro implementation, the wellknown and established "Business and Accounting Software Developers Association" (BASDA) euro benchmarking test data (http://www.basda.org/) is used, with the rates summarized in Table 2.

TABLE 1

Actual Currency Conversion Rates

\begin{tabular}{|c|c|c|}
\hline Country & 1 Euro = & Code \\
\hline Austria & 13.7603 & ATS \\
\hline Belgium & 40.3399 & $\mathrm{BEF}$ \\
\hline Finland & 5.94572 & FIM \\
\hline France & 6.55957 & FFR \\
\hline Germany & 1.95583 & DEM \\
\hline Ireland & 0.78763 & IEP \\
\hline Italy & $1,936.27$ & ITL \\
\hline Netherlands & 2.20371 & NLG \\
\hline Portugal & 200.482 & PTE \\
\hline Spain & 166.386 & ESP \\
\hline
\end{tabular}

Source: http//www.cnn.com/WORLD/europe/9812/31/euro.01/ 
TABLE 2

BASDA Euro Benchmarking Test Data

\begin{tabular}{|c|c|c|}
\hline Country & 1 Euro = & Code \\
\hline Austria & 13.9119 & ATS \\
\hline Belgium & 40.7844 & BEF \\
\hline Finland & 6.01125 & FIM \\
\hline France & 6.63186 & FFR \\
\hline Germany & 1.97738 & DEM \\
\hline Ireland & 0.796244 & IEP \\
\hline Italy & 1957.61 & ITL \\
\hline Netherlands & 2.22799 & NLG \\
\hline Portugal & 202.692 & PTE \\
\hline Spain & 168.22 & ESP \\
\hline
\end{tabular}

If a company wants to convert from Belgian Francs to Austrian Shillings, typically they would simply multiply the conversion rate times the number of Belgian Francs to get the equivalent number of Austrian Shillings. To convert back, they would multiply the inverse of the conversion rate in order to determine the equivalent number of Belgian Francs. Assume that the exchange rate between Belgian Francs and Austrian Shillings is either .3411 francs per shilling or 2.9316 shillings per franc. Under the first exchange rate, 12,345,676 Belgian Francs would convert to 4,211,110 shillings, yet, 4,211,110 Austrian Shillings would convert to 12,345,290 Belgian Francs under the other rate. Depending on which rate is used and how it is implemented can lead to arbitrage opportunities, in this case a difference of 386 Belgian Francs, because of the choice of the exchange currency and rounding.

When the euro was chosen for implementation, its developers wanted to limit the ability of speculators to gain from the transition. As a result, they established conversion requirements and chose to require triangulation (the regulations are summarized in Exhibit 2). Triangulation conversion of Belgian Francs to

\section{EXHIBIT 2 \\ Conversion and Rounding \\ Articles 4 and 5 of the Article 235 Regulation}

\section{Article 4}

1. The conversion rates shall be adopted as one euro expressed in terms of each of the national currencies of the participating Member States. They shall be adopted with six significant figures.

2. The conversion rates shall not be rounded or truncated when making conversions.

3. The conversion rates shall be used for conversions either way between the euro unit and the national currency units. Inverse rates derived from the conversion rates shall not be used.

4. Monetary amounts to be converted from one national currency unit into another shall first be converted into a monetary amount expressed in the euro unit, which amount may be rounded to not less than three decimals and shall then be converted into the other national currency unit. No alternative method of calculation may be used unless it produces the same results.

\section{Article 5}

Monetary amounts to be paid or accounted for when a rounding takes place after a conversion into the euro units pursuant to Article 4 shall be rounded up or down to the nearest cent. Monetary amounts to be paid or accounted for which are converted into a national currency unit shall be rounded up or down to the nearest sub-unit or in the absence of a sub-unit to the nearest unit, or according to national law or practice to a multiple or fraction of the sub-unit or unit of the national currency unit. If the application of the conversion rate gives a result that is exactly halfway, the sum shall be rounded up. 
Austrian Shillings requires conversion from Belgian Francs to euros at the established rate, then rounding. Then the euros must be converted to Austrian Shillings at the established exchange rate, and then rounded. As an example, consider converting Belgian Francs to Austrian Shillings. In Table 3 we would have the following operations:

Initial Amount of Belgian Francs 12,345,676

Intermediate Amount of Euros $=12,345,676 * 1 /(40.7844)$

Final Amount of Austrian Shillings $=$ Rounded Intermediate Amount*13.9119

Triangulation will take place only for the three-year period where there are both local and euro currencies. A more extensive example, based on the BASDA benchmarking data (www.basda.org) given by J. D. Edwards (http://www.jdedwards.com/euro/index.asp), is illustrated in Table 3.

\section{Affected Companies}

All companies that do business in EMU countries will be directly affected by the change to the euro, since each such company will do business in euros. As noted by the president of Callaway Golf International (Dunn 1998), if retailers want to pay in a currency then firms have to learn how to deal with that currency. In addition, companies that are a part of the supply chain for firms doing business in EMU countries may be affected. For example, U.K. companies that supply Siemans and Daimler Benz will be expected to provide invoices in euros (Software Echo 1997). Further companies that ultimately want to do business with EMU countries will also be affected. As a result, many companies in non-EMU countries will still need systems that can handle the euro. The Gartner Group has predicted that ultimately all Fortune 1000 companies will be affected.

\section{IMPACT ON ACCOUNTING INFORMATION SYSTEM APPLICATIONS}

\section{Affected Information System Applications}

There is limited information about which systems within an organization will be affected by the euro. However, according to Violino (1998), IBM expects that 80 percent of its information technology applications in its European operations will be affected.

Further, virtually all accounting and financial information system applications will be affected. For many companies this will mean most of their applications, since typically, at some level, accounting systems interface with other systems. Since accounting and financial packages will be impacted, this also means that "enterprise resource planning" (ERP) systems, such as SAP, also will be affected.

TABLE 3

Triangulation

$\begin{array}{ll}\begin{array}{l}\text { Initial Amount } \\ \text { in } \mathbf{B E F}^{\mathbf{a}}\end{array} & \begin{array}{l}\text { Intermediate } \\ \text { Euro Amount }\end{array} \\ & \frac{302,705.84}{12,345,676.00}\end{array}$

\begin{tabular}{l}
$\begin{array}{c}\text { BASDA Final } \\
\text { Amount }^{\mathbf{b}}\end{array}$ \\
\hline $4,211,213$ \\
$1,819,640.47$ \\
$2,007,502.74$ \\
$598,564.47$ \\
$241,027.71$ \\
$592,579,977$ \\
$674,425.58$ \\
$61,356,051.80$ \\
$50,921,176$
\end{tabular}

\begin{tabular}{l}
\multicolumn{1}{c}{$\begin{array}{c}\text { Currency } \\
\text { (Country) }\end{array}$} \\
\hline ATS (Austrian Schilling) \\
FIM (Finish Markka) \\
FFR (French Franc) \\
DEM (German Mark) \\
IEP (Irish Punt) \\
ITL (Italian Lire) \\
NLG (Netherlands Guilder) \\
PTE (Portuguese Escudos) \\
ESP (Spanish Pesatae)
\end{tabular}

a Belgian francs.

b BASDA data based upon "BASDA Triangulation Test Pack" published July 1998. 


\section{Accounting Information System Requirements Brought About by the Euro}

The introduction of the euro will have a wide range of changes in requirements for accounting information systems (e.g., Dekker [1997] and others).

1. Legacy systems will require multiple updates. Unlike present day relational database systems, many legacy systems redundantly store data items (e.g., currency figures). In these systems, all instances of each redundantly stored currency data item will need to be updated to the same euro figure.

2. Systems must do triangulation. All those systems using processes related to currency exchanges, will have to be updated to reflect changes in the way conversion is done, using triangulation, rather than traditional inversion conversion.

3. Multiple currencies. Since both euro and local currencies can be used during the transition period, systems will need to allow recording and display of both home currency and the euro for each transaction. Inventories of both currencies will need to be kept as long as both are used. The existence of multiple currencies potentially exposes a company to the risk that payments are made in the wrong amounts of a currency. For example, as in Table 3, a bill for 302,706 euros incorrectly might be paid as 4,211,213 euros if clerks use the wrong currency amount.

4. Minor payment differences. Systems will need to be changed to accommodate minor differences in payments. Since customers can pay their bills in either euros or the home country currency, triangulation rounding can create a situation where there are differences in the equivalent between what is billed and what is paid when different currencies are involved. Few systems have been built to accommodate differences in payments and what is billed. Further, few systems currently accommodate billing in one currency and payment in another (Software Echo 1997). In addition, such differences will carry forward to the general ledger, which will also have to accommodate minor differences.

5. Restatement of financial reports. Firms must restate previous financial statements in euros, which raises other questions including the following: Who determines whether historical numbers will need to be restated? How much of the historical data will be restated? Will firms have the restated historical numbers attested to?

6. Inconsistent use of decimals. In some monetary systems, e.g., Belgium and Italy, decimal places are not used. As a result, systems designed for these currencies will need to be updated to accommodate the euro's decimal places.

7. Number of decimal places. Not only is the existence of decimal places an issue, but also the number of decimal places is an issue. In order to assure that rounding is done at the appropriate level, six decimal places are required to accommodate the euro.

8. Input validation will need to accommodate multiple currencies. Input validation will need to change to accommodate the existence of a new currency and multiple currencies. Reconciliation tests will need to allow for and accommodate differences due to rounding.

9. Internal documents. Typically, most of a firm's documents, input, and output will need to be changed to accommodate the multiple currencies.

10. Reporting capabilities. Reporting capabilities will need to be examined closely. For example, reports are often based on currency values exceeding some "threshold" amount. In some cases firms will need to change the bases of those thresholds to accommodate the euro. In addition, reports will often need to have the ability to display two or three currencies simultaneously.

11. Currency fonts will need updating. Finally, currency fonts will need to be updated to include the new symbol for the euro. Apparently, Microsoft has announced that it will accommodate the euro symbol in its 32 bit applications, but not in legacy applications, such as Windows 3.1 (http:// www.microsoft.com/windows/euro.asp).

\section{Similarities and Differences Between the Euro and Year 2000 Problems}

The euro problem and the Year 2000 (Y2K) problem are closely related. In each case software must 
be updated to accommodate changes in the data. Enterprise resource planning (ERP) systems are being sold as answers to both problems. Further, both the euro and Y2K can impact supply chains and electronic exchange of data. If vendors' software is not euro compliant then data exchanged electronically will not be valid. As with the Y2K problem, few firms are isolated enough to not worry about trading partners.

However, where the Y2K problem is a relatively mechanical problem caused by a lack of sufficient space for the year, the euro problem is more than that. Unlike the Y2K problem, computing processes must change with the euro, due to procedures such as triangulation. As noted by a project manager for Bloomberg, a provider of financial information and news:

For us the euro was much more difficult than Y2K. The year 2000 is just a matter of making sure your software works. With the euro people's business will be different and so our applications have to be different too." (Dunn 1998, C4)

Introduction of the euro is changing the nature of many basic business problems, as noted above. As a result, it is not surprising that a Chase Manhattan project manager for the euro has indicated that fixing the euro problem will be harder than fixing the Year 2000 problem (Violino 1998). Or as noted by the CEO of the British-based Business and Accounting Software Developers Association (Violino 1998, 51), "For IT professionals, the complexities of preparing to meet the requirements for EMU are even far more onerous than meeting those for the Year 2000."

\section{Competition for Resources with Year 2000 Projects}

Similarities between $\mathrm{Y} 2 \mathrm{~K}$ and the euro problem and the corresponding competition for resources have not gone unnoticed. For example, Alan Greenspan, Chairperson of the United States' Federal Reserve System noted in his semiannual report to Congress in February 1998 that the euro may be delaying resolution of the year 2000 problem (Sorkin 1998, 1).

I do know that we at the Federal Reserve are aware of the fact that because of the tremendous amount of resources moving toward a single-currency implementation that other resources to confront the computer issues are lacking.

The Gartner Group (Jones 1997b) has indicated that the Y2K problem has absorbed so many resources that 48 percent of surveyed companies said that they had vacant programmer positions. In addition, 70 percent indicated that they would need to increase IT staff and budgets to address Y2K or euro problems. Finally, competition for resources has led to prioritization of both the Y2K problem and the euro problem, often with the euro on top. As noted by Neaman Bond Associates (1997, 16), "Many business managers (and German IT people) prioritize the euro ahead of the Year 2000."

\section{Managing Y2K and Euro Projects}

Some companies have chosen to manage both Y2K and euro projects simultaneously, while others have chosen to manage them separately. In an Information Week survey, Violino (1998) reported that 29 percent of firms surveyed indicated that they would combine euro and Y2K efforts, 67 percent said that they would not combine efforts and 4 percent reported that they did not know if they would combine efforts. Similarly, Neaman Bond Associates (1997) found that roughly 52 percent of firms separated the two projects, 29 percent combined them, 13 percent did only Y2K, 2 percent did only euro, and 4 percent did not know. Ford and General Motors are reportedly among the firms that have combined both projects (Violino 1998).

Neaman Bond Associates (1997) found that departmentally, IT was most frequently in charge of the project, whether it was the euro or $\mathrm{Y} 2 \mathrm{~K}$. For those specified, finance was the second most frequently referenced (see Table 4).

\section{CONVERSION ISSUES AND PROBLEMS}

Introduction of the euro is more than just a change in currency and the corresponding need to change the supporting information systems: the euro changes the solution to basic business decision-making 
TABLE 4

Who Manages the Problem? ${ }^{a}$

\begin{tabular}{|c|c|c|}
\hline Who Is In Charge & Euro \% & Y $2 K \%$ \\
\hline CEO & 9 & 10 \\
\hline Finance & 32 & 12 \\
\hline IT & 43 & 65 \\
\hline Unspecified & 17 & 21 \\
\hline No Response & 8 & 2 \\
\hline
\end{tabular}

a Numbers do not add to 100 percent in original study.

problems. This basic change leads us to question the extent to which firms are prepared for the change to euros, and the types of solutions available to them. In addition, conversion to the euro ultimately leads us to consider the role of euro system audits.

\section{Impact on Business Problems and Strategies}

The euro will cause many firms to reassess business decisions and strategies. Marketing and product issues, such as what features should be packaged together in a product and how should that product be priced, must be reexamined. Currently many products are priced to take advantage of psychological price breaks. For example, in Belgium automobiles have been advertised at, e.g., 699,000 Belgium Francs. What happens if price breaks using the new euro are not at a psychological price break? For example, will the equivalent in 17,328 euros have the same psychological advantage? Would buyers respond the same? Further, what happens during the transition period when both euro and local currencies are used? Should both currencies be at psychological breakpoints or should only one (e.g., the local currency) be at the psychological break point?

The configuration of business operations may also change. Costs of operations in EMU countries will become more transparent and many issues of exchange risk will be eliminated. This might prompt European businesses to seek changes in the location of warehouse and production facilities.

Existing contractual relationships will have to be reassessed and rewritten in euros. Since packaging and business operation configurations are likely to change, reestablishing existing contracts is likely to be an important part of future operations influenced by the euro.

The euro also impacts firms outside the EMU. Adapting to euro requirements can be quite costly and may influence a firm's decision to do business in the EMU. Further, as noted by Knowles (1997), a number of United States companies have noted other strategies that will be influenced. For example, Motorola's hedging strategy will be affected, forcing their hedging information systems to be able to accommodate the euro.

Finally, some EMU firms may need to re-denominate their share capital in order to have a more reasonable corporate law capital structure (e.g., Deloitte Touche Tohmatsu International 1998, 10-11; PriceWaterhouseCoopers 1998, 5). Shares may have to be consolidated to convert share prices from the local currency to logical levels in euros.

\section{Extent of Preparedness}

A number of firms, including KPMG (1996, http://www.kpmg.co.uk/uk/services/manage/emu.html), Price Waterhouse (1997) and the Gartner Group (Jones 1997c) have issued reports on the extent to which firms have prepared for the euro currency. These surveys had similar findings. KPMG found that two-thirds of the firms surveyed had no plans in place to cope with the introduction of the euro. In general, firms did not know what it would cost to make changes to accommodate the euro; firms had not isolated any new opportunities or organizational implications. Further, firms had little idea of what the change to the euro would cost. German companies were most prepared, while United Kingdom firms 
were least prepared. Financial service organizations were better prepared than manufacturing or service sectors. Less than one-third of the firms surveyed thought that the change to the euro would strongly influence their information systems.

Price Waterhouse (1997) found that one quarter of the respondents rated the quality of the EMU information within their organization as high, while one-half of the firms had yet begun to undertake any formal assessment of the likely impact of the euro on their business. The survey also found that company treasurers are frequently placed in charge of EMU change efforts.

Similarly, the Gartner Group (Jones 1997c) found in a survey of attendees at a Gartner Group Seminar that many companies were not fully aware of the impact of the euro. As noted by Jones (1997c, 3) roughly 70 percent of nonfinancial organizations and 45 percent of financial organizations categorized themselves as organizations where "business staff and IT staff are generally unaware of the EMU process."

Further, as noted by Deloitte \& Touche (http://www.deloitte.co.uk/news/key.html), a recent survey in the United Kingdom (U.K.) found that few retailers were ready for the euro. "It may be a saviour that the Government has decided not to join the first wave of single currency adopters as 87 percent of retailers said that they weren't ready or didn't know if they were ready for the euro."

\section{Assessment Tools}

Neaman Bond Associates (1977) found that 20 percent of the firms surveyed are planning on buying tools to facilitate assessment of the impact of the euro on a firm and to provide feedback on their progress. Deloitte \& Touche has developed "Eurocheck3," (http://www.deloitte.co.uk/services/ audit/euro.html) a computer-based knowledge base designed to allow a company to assess the impact of the euro. In addition, Deloitte \& Touche also has developed "Fasttrack4Euro," a methodology to develop and implement the Euro strategy. The Gartner Group also has developed a methodology to assess the impact of the euro and the EMU (Jones 1997d). Other consulting firms, such as Cap Gemini (http://euro.capgemini.com/) also have developed methodologies and have large consulting bases in helping firms adapt to the euro.

\section{Software Solutions}

As with the $\mathrm{Y} 2 \mathrm{~K}$ problem there are a number of potential solutions to the euro problem, including, fixing the code and implementing new euro compliant software to replace existing software. Fixing code requires line-by-line analysis of a program. Unfortunately, such an approach can be quite costly. For example, Jones (1997a) suggests that estimates of $\$ 1.10$ to $\$ 1.50$ per line of code, similar to those for the Y2K problem, will be incurred to make programs euro compliant.

An alternative solution being used by larger firms is to implement an enterprise resource planning (ERP) systems, such as Baan, J.D. Edwards, Oracle, PeopleSoft or SAP. The major ERP vendors have committed to having euro-compliant versions available (http://techweb.cmp.com/iw/666/66iueu2.htm). SAP recently released an update for its R/3 3.0 software (http://www.sap.com/euro/index.htm). In addition, SAP's R/3 version 4.0 and 4.5, are euro compliant. Reportedly, Baan, J.D. Edwards and PeopleSoft also are euro compliant (http://www5.baan.com/cgi-bin/bvisapi.dll; http:// www.jdedwards.com/newsroom/archive/eurostory.asp; http://www.peoplesoft.com/en/why_peoplesoft /emu/pdf/psftemu1997.pdf). In addition, Oracle Financial Applications (http://www.oracle.com/html/ euro.html) release 11.0 is euro compliant.

\section{Estimates of Costs to Convert to the Euro}

Industry-wide costs of making Europe's software euro compliant have been estimated by the Gartner Group to exceed $\$ 100$ billion (Jones 1997a). Their estimate increases to $\$ 150$ to $\$ 400$ billion when worldwide operations are considered (Sorkin 1998). Neaman Bond Associatess (1997) have estimated the total cost in Europe at $\$ 200$ billion.

At the individual company level, a recent Information Week (Violino 1998) survey of 100 Information Technology Managers found the cost estimates presented in Table 5.

Many sources suggest that attaining euro compliance will be more costly than $\mathrm{Y} 2 \mathrm{~K}$ compliance. For 
TABLE 5

Company Expenditures for the Euro

\begin{tabular}{cll} 
Percent of Companies & & \multicolumn{1}{c}{ Cost (in dollars) } \\
22 & & More than $2,000,000$ \\
17 & & $1,000,001-2,000,000$ \\
11 & $600,001-1,000,000$ \\
9 & $300,001-600,000$ \\
15 & $100,001-300,000$ \\
26 & 100,000 or less
\end{tabular}

example, according to Violino (1998), IBM's euro conversion costs will exceed its Y2K costs. Further, Lillington (1998) indicates the Chief Executive Officer of the British-based Business and Accounting Software Developers Association, has noted that conversion for the euro will be up to four times as costly as Y2K changes.

\section{Importance and Role of Euro System Audits}

A number of researchers (e.g., Jones 1997a) suggest that banks will be interested in knowing whether a company's software is euro compliant. Further, trading partners will be interested in knowing whether a company's software is euro compliant. In addition, as noted by Public Accounting Report $(1997,5)$ "Auditors should be worried if a company says it hasn't addressed this matter." As a result, euro system "audits" could prove to be a useful vehicle to provide assurance that firms have euro-compliant software.

Auditors face a number of concerns regarding the euro's impact on accounting systems. For example, could the euro cause auditors to issue a qualified opinion, and if so, how severe must the problem be in order to require a qualified opinion? Other issues include: what are the implications of the euro on contingent liabilities? Assurance practices in the major consulting firms have offered solutions to many frequently asked questions (e.g., KPMG 1998; PriceWaterhouseCoopers 1998). Answers to such questions vary from country to country.

There has apparently been limited attention to the euro from accounting standard setters. However, the United Kingdom (U.K.) group ASB (Accounting Standards Board, http://www.icaew.co.uk/) has recently issued preliminary guidance on some accounting issues for U.K. firms in its UITF (Urgent Issues Task Force) Abstract 21 Accounting Issues Arising from the Proposed Introduction of the Euro. In addition, they have also published a set of guidelines for published financial statements. Example suggestions include that financial statements be published in both the company's national currency and in euros and that contingent liabilities be evaluated at conversion rates as of December 31, 1998, since that best reflects the economic reality at that date (http://www.icaew.co.uk/depts/td/tditf/pubs/chartech/euro/page4.htm).

\section{CONCLUSIONS AND RESEARCH OPPORTUNITIES}

This final section identifies additional research issues relating to the emergence of the euro and summarizes the opportunities and challenges that the euro provides for accountants, auditors, and consultants.

\section{Research Issues}

Although much of this article has been aimed at practical issues associated with the euro, the euro offers a number of research opportunities. This section identifies some of the research opportunities in the areas of software engineering, reengineering, supply chain management and international accounting. This list is not meant to be all encompassing, but instead to suggest some interesting research issues. 
Although seemingly ignored by accountants and auditors, there are a number of well-established costing models in software engineering (Boehm 1981; Kemerer 1987). The euro provides an opportunity to apply these costing models to determine if existing costing models work for the software engineering changes required to accommodate the euro. If any anomalies exist then that offers the opportunity for basic research in developing new costing models. Software engineering offers other important areas of research in accounting systems (O'Leary 1988), such as program specification, design and development, and software testing. Viable research issues might include what types of program specification, design, development, and testing are most effective in euro program adaptations.

Firms may see reengineering processes as either an opportunity or a necessity, when faced with changes to accommodate the euro. A number of questions arise including the following: What happens to processes when the focus is on fixing a euro problem? If we implement an ERP in order to mitigate euro problems, then what basis is there for process choice if the only choice rationale is fixing the euro problem? To what extent have EMU companies reengineered as part of their euro solutions?

Increasingly, firms are linking with other firms in their supply chains. In such settings, there are increased vulnerabilities to limitations of the weakest firm in the supply chain link. Research could focus on what firms are doing to facilitate supply chains and minimize problems in the supply chain due to the euro. For example, what kinds of euro-compliance analysis is being performed in supply chains? As the euro is introduced, additional research can analyze actual supply chain problems introduced by the euro.

Implementation for the euro varies across countries (KPMG 1998). As a result, the euro provides an opportunity for cross-sectional analysis of accounting practices and a set of research issues for international accounting, based on the way the countries respond to the euro change.

\section{Opportunities for Accountants, Auditors, Consultants, and Researchers}

There is a wide range of opportunities for accountants, auditors, and consultants, with the emergence of the euro. Since virtually all financial applications are affected, firms will need to be able to answer their clients' questions regarding the euro and changing their clients' systems to be euro compliant. Accounting systems will need to accommodate multiple currencies, with and without decimal places, using triangulation.

Because there are many new system requirements, clients will be faced with either implementing new systems or fixing their old ones. In any case, making systems euro compliant will result in competition with the $\mathrm{Y} 2 \mathrm{~K}$ problem, so that issues such as whether the $\mathrm{Y} 2 \mathrm{~K}$ and euro problems should be managed separately will need to be addressed.

However, when approaching clients, accountants and consultants need to think bigger than just changes to systems. Introduction of the euro can lead to substantial changes in business strategies and decision making. For example, firms' strategies in areas such as pricing will need to consider new psychological break points. Clients need to be made aware of the extent to which these changes in strategy are necessary and available. Further, clients should consider the change to the euro as an opportunity to reengineer processes to facilitate adoption of the new monetary unit. Finally, clients may restructure their capital to accommodate the euro.

Many clients will need assistance. For example, clients that do business in the EMU or are part of the supply chain of an EMU company likely will need euro-system capability. Clients investigating the opportunities of doing business in Europe will need euro capabilities.

As an auditor, there is a need to ensure that clients consider the affect of the euro on their firms. Accordingly, auditors should be concerned if their clients will be affected by the euro, but have not taken steps to address the systems and business issues. This article has examined issues such as who is affected by the euro, the extent of euro preparedness, solutions and costs of fixing the euro problem, and importance of euro system audits.

Researchers should see the euro as offering unique data from a test laboratory. Software engineering costing models can be used to see if the unique nature of the euro conforms to software development models. Firm-based data on reengineering in response to the euro change can be developed and analyzed. Although supply chains are in their infancy, researchers can examine, for example, the extent to 
which adopting information systems to the euro plays a role in changes in market share. Finally, the euro provides an opportunity to investigate issues such as harmonization of accounting principles.

\section{REFERENCES}

Boehm, B. 1981. Software Engineering Economics. Englewood Cliffs, NJ: Prentice Hall.

Condon, R. 1997. Finance software may get snagged by European currency demands. Computerworld $<\mathrm{http}: / /$ www.computerworld.com/home/features.nsf/All/980309euroy2klinks>

Dekker, P. 1997. Preparing financial information systems for the Euro. (December) <http://www.ispo.cec.be/ y2keuro/src/wdiseuro.htm>

Deloitte Touche Tohmatsu International. 1998. Managing the Euro. London, U.K.: Deloitte Touche Tohmatsu International.

Dunn, A. 1998. Meet the millennium bug's European cousin. Los Angeles Times (December 21): C1, C4.

Frank, R. 1998. Enter Captain Euro, unlikely new face of a united Europe. Wall Street Journal Europe (December 14): $1,6$.

Henning, C. 1997. Cooperating with Europe's monetary union. Institute for International Economics (May) <http:// www.iie.com/CATALOG/CURRENCY/gimue.htm>

Jones, N. 1997a. The IT cost of a single Europe currency. Gartner Group (May 7). 1997b. The year 2000 will be late in Europe. Gartner Group (May 29).

1997c. Credit rating: Measuring progress toward EMU. Gartner Group (July 30).

1997d. EMU: The impact analysis. Gartner Group (September 29).

Kemerer, C. 1987. An empirical validation of software cost estimation models. Communications of the ACM (May): 416-427.

Knowles, A. 1997. Euro: Creation of a new currency. Datamation (November): $80-83$.

KPMG. 1998. Overview of the tax and audit implications of the euro, edition 3.1. $\triangleleft$ ttp://www.kpmg.com/library/ 98/august/Eurobk3-1.pdf>

Lillington, K. 1998. Pounds, francs, marks, lira, headaches. San Jose Mercury News < http://www.mercurycenter.com/ resources/search/>

Neaman Bond Associates. 1997. Strategic business systems and the single European currency. (December.)

O'Leary, D. 1988. Software engineering and research in accounting information systems. The Journal of Information Systems (Spring): 24-40.

Price Waterhouse. 1997. 1997 EMU corporate treasury survey. (October.)

PriceWaterhouseCoopers. 1998. Accounting for the euro. <http://www.pwcglobal.com/extweb/newcojou.nsf/ docidmanagement/1879CD1859090357852566320076B390?opendocument>

Public Accounting Report. 1997. Are you ready for the euro? Public Accounting Report (November 15): 1, 4.

Software Echo. 1998. Hot features: The bumpy ride to the EMU. \http://www.hotecho.org/archive/se28/mainfeature/ mainfeature11.html>

Sorkin, A. 1998. Change to euro currency may cause computer snafu. $<$ http://www.star-telegram.com/news/doc/ 1047/1:BIZ12/1:BIZ12030898.html>

Violino, B. 1998. The euro: Are you ready? Information Week (January 26): 44-58. 